OPEN ACCESS

Edited by:

Ana Preto,

University of Minho, Portugal

Reviewed by:

Dario Coletti,

Sapienza Università di

Roma, Italy

Sharon Ross,

National Cancer Institute

$(\mathrm{NIH})$, United States

*Correspondence:

Kenneth A. Schwartz

schwart7@msu.edu

Specialty section: This article was submitted to Clinical Nutrition,

a section of the journal

Frontiers in Nutrition

Received: 13 November 2017

Accepted: 25 January 2018

Published: 23 February 2018

Citation:

Schwartz KA, Noel M, Nikolai M and Chang HT (2018) Investigating the

Ketogenic Diet As Treatment for

Primary Aggressive Brain Cancer:

Challenges and Lessons Learned.

Front. Nutr. 5:11.

doi: 10.3389/fnut.2018.00011

\section{Investigating the Ketogenic Diet As Treatment for Primary Aggressive Brain Cancer: Challenges and Lessons Learned}

\author{
Kenneth A. Schwartz ${ }^{1 *}$, Mary Noel', Michele Nikolai ${ }^{2}$ and Howard T. Chang ${ }^{3,4}$ \\ 'Osteopathic Medical Specialties, Colleges of Human and Osteopathic Medicine, Michigan State University, East Lansing, \\ MI, United States, ${ }^{2}$ Department of Nutrition, Sparrow Hospital, Lansing, MI, United States, ${ }^{3}$ Department of Pathology, \\ Sparrow Hospital, Lansing, MI, United States, ${ }^{4}$ Department of Neurology and Ophthalmology, Colleges of Human and \\ Osteopathic Medicine, Michigan State University, East Lansing, MI, United States
}

Survival of glioblastoma multiforme (GBM) with the current recommended treatment is poor. Reported median survivals are approximately 8-15 months. Based on recent publications from animal models, combining cancer drugs, radiation, and diet-metabolic treatments may be a new route to better survivals. To investigate this possibility, we have begun a clinical trial that has enrolled 15 subjects using a ketogenic diet (KD) as an addition to current standard treatments that include surgery, radiation therapy, and chemotherapy. Of the 15 enrolled, 10 completed the protocol. This perspective describes the challenges and lessons learned during this clinical trial and discusses the critical elements that are essential for investigating treatment with a KD. We also reviewed and compared various types of KDs. We believe that the diet selected should be standardized within individual clinical trials, and more importantly, the patients' blood should be monitored for glucose and ketones twice daily so that the supervising dietitian can work with the patient and their caregivers to make appropriate changes in the diet. Compliance with the diet is best in highly motivated patients who have excellent home support from a family member or a friend who can help to overcome administrative, physical, and cognition deficiencies associated with the disease. Treatment of GBM using a KD represents a reasonable investigative approach. This perspective summarizes the challenges and lessons learned implementing and continuing KD therapy while the patients are concurrently being treated with radiation and chemotherapy.

Keywords: ketogenic diet, glioblastoma, pilot study, lessons learned, blood ketones

\section{INTRODUCTION}

During the period between 2008 and 2012, the annual number of patients afflicted with glioblastoma multiforme (GBM), the most aggressive primary brain cancer, in the United States was calculated to be 10,787 , and the estimated number of new patients for 2016 is $12,120(1,2)$. Current treatment protocols for treating primary brain cancers utilizes a multidisciplinary coordinated approach usually involving neurosurgery, radiation therapy, and chemotherapy $(3,4)$. However, the median survival period for GBM patients remains dismal, ranging from 8 to 15 months $(5,6)$. The addition of temozolomide to radiation therapy prolongs survival slightly less than 3 months (5). 


\section{RATIONALE: KETOGENIC DIET (KD) AS ANTICANCER THERAPY}

Individual case reports together with studies in rodents suggest that a KD might be a useful adjunct to the current treatment approach. Normal brain cells and tumor cells may differ in their ability to utilize ketones as a metabolic fuel $(7,8)$. Under physiologic conditions, normal brain cells can obtain energy from either glucose or ketones. In contrast, many tumors become more dependent on glucose for energy support because they have decreased expression of critical ketolytic enzymes $(9,10)$. Evaluation of enzymatic expression using immunohistochemistry showed that 14 of 17 patients had decreased expression of ketolytic enzymes (10). However, at least in some instances, ketone bodies were detected using proton-magnetic-resonance-spectroscopy in brain tumors of patients who were being treated with a KD (11). It is noteworthy that hyperglycemia is associated with adverse prognosis and postoperative function loss in GBM patients. Patients treated with KD tend to have lower blood sugar levels $(12,13)$. Another plausible rationale focuses on $\beta$-hydroxybutyrate, the main ketone produced during ketosis, which is an endogenous and specific inhibitor of class 1 histone deacetylases capable of activation of specific genes to protect mice against oxidative stress (14). Indeed, the $\mathrm{KD}$ affects expression of proteins associated with angiogenesis, invasion potential, and vascular permeability in a mouse glioma model (15). Investigations on seizures and traumatic brain injury showed decreased oxidant production with ketones possibly from improvement in mitochondrial function which could also contribute to anticancer activity $(16,17)$.

The anti-brain cancer effect of ketones and the KD has been observed in several rodent models (18). Energy-restricted KDs (ERKD) limited the growth of orthotopically transplanted brain tumors in these animals (19). Mice fed ERKD demonstrated higher blood ketone concentrations and reduced brain tumor growth that was associated with an increased rate of apoptosis. KDs also increase the efficacy of metabolic inhibitors for treatment of astrocytomas in rodent models (20). Decrease growth of GBM cell lines was demonstrated in cell cultures treated with $\beta$-hydroxybutyrate, the main ketone produced with ketosis (21). In addition, decreased brain tumor growth and increased animal survival was observed in an orthotopic xenograph animal model treated either with a standard KD or a KD supplemented with medium-chain triglycerides (MCT) (21). These reports provide support for investigating the utility of $\mathrm{KD}$ in patients with primary brain malignancies.

Ketogenic diets have been suggested as adjuvant cancer therapy and specifically as metabolic therapy for malignant gliomas $(22,23)$. Our review of the reported cases of glioma patients revealed five patients who responded to treatment with KD (24). Based on these patients and the long and safe history of the use of KDs to treat hard-to-control seizures, we began a pilot protocol to treat primary aggressive brain cancers with a KD (25-27). We agree with the recent review calling for rigorous scientific data to fairly evaluate the role of metabolic treatments for aggressive primary brain cancers (28). The current perspective describes the challenges and lessons learned in the patients enrolled in our trial, under either the initial or the revised protocols.

\section{CLINICAL PROTOCOL AND EXPERIENCE WITH THE KD}

To date, after signing informed consent 15 patients have been enrolled, and 10 completed treatment with the protocol that was IRB approved (11-452s) and Clinical Trails registered (NCT01535911). Two patients were studied with the original protocol that stipulated starting the $\mathrm{KD}$ after they have failed conventional treatments. An additional eight patients have completed the 6 weeks of revised protocol that starts the KD at the same time as the initial radiation and chemotherapy, and continues it for 6 weeks. This protocol has the primary objectives of investigating side effects attributable to the $\mathrm{KD}$, as well as noting tumor response and time to progression. The inclusion criteria are that participants must be over 16 years of age, have histologically confirmed diagnosis of GBM, have an ECOG performance status of $\leq 2$, a life expectancy of $>3$ months, can tolerate a high-fat diet, and have the ability to give informed consent. Our exclusion criteria are that participants may not have diabetes mellitus, may not have had a cholecystectomy within a year prior to entering the study, do not have any malignancy other than the brain cancer, have not participated in another investigational study within 2 weeks prior to this study's entrance, do not have brain metastasis from nonbrain tumor, do not have any major comorbidity such as liver, kidney, or heart failure, and are not pregnant. The protocol $\mathrm{KD}$ is caloric balanced, based on the patient's starting weight. The KD diet is constructed so that the ratio in grams of fat to combined grams of protein and carbohydrates is $3: 1$. Before starting and after completing the $\mathrm{KD}$ protocol, the patients will have a history and physical exam along with blood for complete blood counts, chemistries lipids, and uric acid. During the 6 weeks of KD, the patient records their daily weight, and twice daily measurements of blood glucose and ketones obtained mornings prior to eating and evenings $2 \mathrm{~h}$ after eating. Each patient is given an Omron model HBF-400 scale for their daily weights and an Abbot Precision Xtra Meter with test strips to measure their blood ketones and glucose twice daily. Participants receive dietary instruction by a registered dietitian who develops a meal plan and menus for each subject. In addition, a dietitian calls or visits patients regularly (at least once a week) throughout their time on the KD.

\section{PROTOCOL REVISION, TOLERABILITY, AND SIDE EFFECTS}

We revised our protocol based on a report, in a rodent model, that 9 of 11 mice with a transplanted primary brain tumor that were treated with a KD along with radiation therapy survived, whereas all of the control mice and mice treated with just radiation therapy or just the KD died (29). The success of this simultaneous dual treatment in animals prompted a revision of our protocol so that patients' initial post-surgery treatment includes a KD begun at the same time as radiation therapy and chemotherapy. Eight highly motivated study patients were able to maintain ketosis for 6 weeks with support from their family or caregivers. Participants maintained blood glucoses under $100 \mathrm{mg} / \mathrm{dl}$ and blood ketones around 1-2 mM on the average. All participants lost weight, averaging about $5 \mathrm{lbs}$. Combining the KD with standard-of-care 
radiation and chemotherapies did not add any significant side effects.

\section{COMPARISONS OF DIFFERENT KDS}

Our current KD protocol treats patients for 6 weeks, beginning at the same time as they start their radiation therapy and chemotherapy. The diet is calorie balanced, based on the patient's starting weight, and monitored with twice daily measurements of blood glucose and ketone concentrations to guide diet modifications, if necessary. Because a high-fat KD diet is significantly different and much less palatable than the patients' usual diet, 6 weeks was as long as our patients could tolerate the KD. If the patient and their family or caregivers are highly motivated, then it is possible to maintain ketosis for 6 weeks.

\section{KDs USED FOR BRAIN CANCERS}

The diet currently used in our study is calorically balanced and uses a 3:1 ratio in grams of fat to combined grams of carbohydrates and fat. Table 1 includes case reports and clinical trials using KD therapy for patients with brain cancers. Different protocols vary in the timing (at the beginning of treatment, throughout treatment, or after conventional treatments) and the duration of the diet intervention. Most of the reported patients were treated with diet therapy along with at least one other conventional treatment modality. The prescribed calories were not consistently based on body weights, and thus the "calorie load" or "restriction" were not equivalent for all subjects in these studies. Most studies also did not document or log the blood glucose and ketones levels. Thus, it is difficult to know if a particular diet was producing ketosis.

\section{KETOGENIC DIETS}

Ketogenic medical nutrition therapy is not a standardized, scripted diet plan (Table 2). The traditional or classic $\mathrm{KD}$ is comprised of a specific fat to carbohydrate $(\mathrm{CHO})$ plus protein (PRO) ratio, fat: $\mathrm{PRO}+\mathrm{CHO})$, usually ranging from a 2:1 ratio (i.e., $2 \mathrm{~g}$ of fat to every $1 \mathrm{~g}$ of $\mathrm{PRO}+\mathrm{CHO}$ ) to the most strict $4: 1$ ratio ( $4 \mathrm{~g}$ of fat to every $1 \mathrm{~g}$ of $\mathrm{PRO}+\mathrm{CHO}$ ) (30). To achieve these defined ratios, all the macronutrients must be calculated specifically and foods for meals are weighed on a gram scale. Based on maintenance calorie needs, it is unlikely that maintenance protein needs for adults can be met using a 4:1 ratio due to increased body weight. Therefore, 3:1 ratio is typically the highest prescribed for adults and is the diet selected for our protocol. Fat in these diets is provided by a combination of unsaturated and saturated long-chain triglycerides contained in oils like olive, corn, and peanut, and may include MCT oil either as pure supplement or coconut oil which contains MCT oil. These diets, when administered properly, induce measurable ketosis.

When the MCT Oil diet is used (Table 2), the diet has a lower total fat: $(\mathrm{PRO}+\mathrm{CHO})$ ratio than the classic KDs. In this plan, instead of weighing foods, exchange lists based on fat are used to prepare meals. Ketosis can be induced but usually only if the ratio is adjusted to the higher range of MCT oil (up to $50-60 \%$ of the fat as MCT oil) (30). The Low Glycemic Index Treatment (LGIT) diet has a fat: $(\mathrm{PRO}+\mathrm{CHO})$ ratio similar to the MCT Oil diet, but in the absence of the relatively high amount of MCT oil, usually does not induce ketosis. This diet also uses exchange lists or household measurements for portion control. The LGIT diet has been used in patients with epilepsy with a success rate similar to the classic KD (31). Its usage for people with cancer has not been documented. The Modified Atkins diet and Atkins diet (AD) both have lower fat: $(\mathrm{PRO}+\mathrm{CHO})$ ratios than the other $\mathrm{KDs}$, but have a lower proportion of carbohydrate than the MCT Oil and LGIT diets $(32,33)$. These ADs, similar to the MCT Oil diet and the LGIT diet, do not measure foods specifically, but use household measures to estimate appropriate portions. As long as protein intake is controlled (not too high) and carbohydrate goals are not exceeded, ketosis can be achieved with $\mathrm{ADs}(34,35)$. Diets that do not require weighing specific foods tend to be easier for patients to follow.

\section{LESSONS LEARNED THAT HELP TO PROMOTE KD IN GBM PATIENTS}

1. Our initial protocol treated patients after they had completed standard-of-care treatments and stipulated that patients had to be hospitalized to teach them about the KD. Our first two patients were hospitalized while being started on the diet. However, after we changed the protocol (to treat patients with the KD after their neurosurgery and beginning at the same time as they were being treated with radiation and chemotherapy), we found that we could initiate the diet as outpatient treatment. All of our subsequent patients have started and maintained the KD without the need for hospitalization.

2. Brain cancer patients frequently have problems in areas like executive functioning, thinking, coordination, and vision that can make instituting and complying with an extremely restricted diet very difficult or almost impossible. Most of our patients required the help of a family member or caregiver to fulfill the KD's requirements.

3. Since this is a life-threatening illness, it was often difficult for caregivers to restrict calorie intake as well as to forbid foods that patients find comforting, familiar and drawn to in a time of illness.

4. The preparation and palatability of the food can be a challenge to the patient as well as caregiver. It is imperative that patients are instructed carefully, and followed regularly with the supervising dietitian to ensure that ketosis has been achieved and is maintained.

5. Hospitalizations in an acute or chronic care facility (including rehabilitation centers, assisted living, or long-term care facility) can be a problem since many of these institutions may be ill equipped to handle the diet with its strict weighing of the food.

6. Because of the dire prognosis of this diagnosis, patients and their families often looked for all potential alternative treatments that may complicate attempts to investigate the efficacy of the $\mathrm{KD}$ as a single variable.

7. The twice daily blood sampling (to measure the ketones and glucose levels) is an added burden to an already stressful situation. However, most of our study patients were able to comply with this protocol stipulation. 
TABLE 1 | Human case reports and studies using various ketogenic diet types for patients with brain tumors.

\begin{tabular}{|c|c|c|c|c|c|c|c|c|c|c|}
\hline PI & $\begin{array}{l}\text { No. of } \\
\text { subjects }\end{array}$ & Diet type & $\begin{array}{l}\text { Calorie } \\
\text { restriction }\end{array}$ & Calorie level & $\begin{array}{l}\text { Length of } \\
\text { study }\end{array}$ & $\begin{array}{l}\text { Type of } \\
\text { ketone } \\
\text { measurement }\end{array}$ & $\begin{array}{l}\text { Blood glucose } \\
\text { measurement }\end{array}$ & $\begin{array}{l}\text { Vitamin/ } \\
\text { mineral } \\
\text { supplement }\end{array}$ & $\begin{array}{l}\text { Commercial } \\
\text { nutrition } \\
\text { supplements }\end{array}$ & Treatment phase \\
\hline \multicolumn{11}{|l|}{ Case reports } \\
\hline Nebeling et al. (36) & 1 & $\begin{array}{l}\text { Ketogenic medium chain } \\
\text { triglyceride (MCT) oil-based } \\
\text { diet (60\% MCT oil, } 20 \% \\
\text { protein, } 10 \% \text { carb, } 10 \% \\
\text { dietary fat) }\end{array}$ & No & $\begin{array}{l}85-125 \% \\
\text { RDA for age; } \\
\text { individual- } \\
\text { lized to allow } \\
\text { for growth }\end{array}$ & 2 months & Blood & Yes & Yes & $\begin{array}{l}\text { MCT oil, } \\
\text { commercial } \\
\text { pediatric formula } \\
\text { for } 1 \text { subject on } \\
\text { tube feedings }\end{array}$ & $\begin{array}{l}\text { Post-chemotherapy for } 1 \\
\text { subject, adjunctive with } \\
\text { chemotherapy for second } \\
\text { subject }\end{array}$ \\
\hline Kalamian et al. (37) & 1 & $\begin{array}{l}\text { Atkins } \times 3 \text { months } \\
\text { then Ketogenic } 3.5: 1 \\
\text { ratio } \times 9 \text { months }\end{array}$ & Yes & $65-85 \%$ RDA & 12 months & Blood & Yes & Yes & MCT oil & $\begin{array}{l}\text { Adjunctive with } \\
\text { Chemotherapy }\end{array}$ \\
\hline Zuccoli et al. (38) & 1 & Ketogenic 4:1 ratio & Yes & $600 \mathrm{kcal}$ & 2 months & Blood & Yes & Yes & Ketocal, MCT oil & $\begin{array}{l}\text { Adjunctive with radiation and } \\
\text { chemotherapy }\end{array}$ \\
\hline Schwartz et al. (24) & 2 & $\begin{array}{l}\text { Energy-Restricted ketogenic } \\
\text { diet }(K D): 3: 1 \text { ratio }\end{array}$ & Yes & $\begin{array}{l}20-25 \mathrm{kcal} / \\
\mathrm{kg} / \text { day }\end{array}$ & 6 weeks & Blood & Yes & Yes & No & $\begin{array}{l}\text { New diagnosis with radiation } \\
\text { and chemotherapy }\end{array}$ \\
\hline PI & $\begin{array}{l}\text { Study open } \\
\text { or closed }\end{array}$ & Diet type & $\begin{array}{l}\text { Calorie } \\
\text { restriction }\end{array}$ & Calorie level & $\begin{array}{l}\text { Length of } \\
\text { study }\end{array}$ & $\begin{array}{l}\text { Type of } \\
\text { ketone } \\
\text { measurement }\end{array}$ & $\begin{array}{l}\text { Blood glucose } \\
\text { measurement }\end{array}$ & $\begin{array}{l}\text { Vitamin/ } \\
\text { mineral } \\
\text { supplement }\end{array}$ & $\begin{array}{l}\text { Commercial } \\
\text { nutrition } \\
\text { supplements }\end{array}$ & Treatment phase \\
\hline \multicolumn{11}{|l|}{ Clinical trials } \\
\hline Klein et al. (26) & Open & Ketogenic 4:1 ratio & Yes & 1,600 & 6 months & Blood and urine & Yes & Yes & $\begin{array}{l}\text { Uses pre- } \\
\text { packaged meals }\end{array}$ & $\begin{array}{l}\text { End stage, after radiation } \\
\text { and chemotherapy as } \\
\text { adjunctive therapy }\end{array}$ \\
\hline Klein (39) & Open & Ketogenic 4:1 ratio & Yes & 1,600 & 6 months & Blood & Yes & Not stated & No & $\begin{array}{l}\text { New diagnosis with radiation } \\
\text { and chemotherapy }\end{array}$ \\
\hline Scheck et al. (40) & Open & $\begin{array}{l}\text { Ketogenic } 4: 1 \times 6 \text { weeks } \\
\text { with radiation/chemo } \\
\text { followed by a modified Atkins } \\
\text { diet (MAD) during monthly } \\
\text { chemotherapy } \times 12 \text { months }\end{array}$ & No & Not stated & 18 months & Blood & Yes & Not stated & No & $\begin{array}{l}4: 1 \text { with radiation/ } \\
\text { chemotherapy, then MAD } \\
\text { with chemotherapy }\end{array}$ \\
\hline Reiger et al. (41) & Closed & unrestricted KD & $\begin{array}{l}<50-60 \mathrm{~g} \\
\text { carbohydrates/ } \\
\text { day }\end{array}$ & Not stated & 6 weeks & Urine & No & No & $\begin{array}{l}\text { Dietary } \\
\text { supplementary } \\
\text { products } \\
\text { provided by } \\
\text { Tavarin }\end{array}$ & $\begin{array}{l}\text { End stage, after radiation } \\
\text { and chemotherapy }\end{array}$ \\
\hline Schwartz et al. (42) & Open & KD: 3:1 ratio & Yes & $\begin{array}{l}20-25 \mathrm{kcal} / \\
\mathrm{kg} / \text { day }\end{array}$ & 6 weeks & Blood & Yes & Yes & No & $\begin{array}{l}\text { New diagnosis with radiation } \\
\text { and chemotherapy }\end{array}$ \\
\hline
\end{tabular}


TABLE 2 | Diet comparison overview.

\begin{tabular}{|c|c|c|c|c|c|c|}
\hline & $\begin{array}{l}\text { Classic ketogenic diet } \\
\text { (KD) 4:1 ratio }\end{array}$ & Classic KD 3:1 ratio & $\begin{array}{l}\text { Low Glycemic Index } \\
\text { treatment 1.5:1 ratio }\end{array}$ & $\begin{array}{l}\text { MCT oil diet } \\
0.67: 1-1.5: 1 \text { ratio }\end{array}$ & Modified atkins $0.79: 1$ ratio & Atkins $0.73: 1$ ratio \\
\hline $\begin{array}{l}\text { Caloric distribution } \\
\text { charts }\end{array}$ & $\begin{array}{l}\text { Carbohydrate - } 2 \% \\
\text { Protein }-8 \% \\
\text { Fat - } 90 \%\end{array}$ & $\begin{array}{l}\text { Carbohydrate - 3\% } \\
\text { Protein - } 10 \% \\
\text { Fat }-87 \%\end{array}$ & $\begin{array}{l}\text { —Carbohydrates - 12\% } \\
\text { - Protein - } 28 \% \\
\text { Fat - } 60 \%\end{array}$ & $\begin{array}{l}\text { Carbohydrate - } 20 \% \\
\text { Protein - } 20 \% \\
\text { Fat -LCT - } 30 \% \\
\text { Fat MCT } 30 \%\end{array}$ & $\begin{array}{l}\text { Carbohydrate - } 6 \% \\
\text { Protein - } 30 \% \\
\text { Fat - } 64 \%\end{array}$ & $\begin{array}{l}\text { Carbohydrate - } 9 \% \\
\text { Protein - } 29 \% \\
\text { Fat - } 62 \%\end{array}$ \\
\hline $\begin{array}{l}\text { Fat portion of } \\
\text { calories }\end{array}$ & $180 \mathrm{~g}$ & $174 \mathrm{~g}$ & $120 \mathrm{~g}$ & $\begin{array}{l}120 \mathrm{~g} ; 60 \% \text { fat: start with } 30 \% \\
\text { MCT, } 30 \% \text { LCT then may adjust up } \\
\text { to } 50 \% \text { MCT and decrease LCT } \\
\text { down to } 10 \% \text { as tolerated }\end{array}$ & $\begin{array}{l}\text { High fat encouraged } \\
\text { Although not measured: At } \\
64 \% \text { of calories }=128 \mathrm{~g}\end{array}$ & $\begin{array}{l}\text { High fat encouraged } \\
\text { Although not measured: At } 62 \% \\
\text { of calories }=124 \mathrm{~g}\end{array}$ \\
\hline $\begin{array}{l}\text { Protein portion of } \\
\text { calories }\end{array}$ & $36 \mathrm{~g}$ & $45 \mathrm{~g}$ & $126 \mathrm{~g}$ & $90 \mathrm{~g}$ (can be adjusted up or down) & $\begin{array}{l}\text { Although not measured }=\text { at } \\
30 \% \text { of calories }=135 \mathrm{~g}\end{array}$ & $\begin{array}{l}\text { Although not measured }=\text { at } \\
29 \% \text { of calories }=131 \mathrm{~g}\end{array}$ \\
\hline $\begin{array}{l}\text { Carbohydrate } \\
\text { portion of calories }\end{array}$ & $9 \mathrm{~g}$ & $15 \mathrm{~g}$ & $54 \mathrm{~g}$ & $90 \mathrm{~g}$ (can be adjusted up or down) & $\begin{array}{l}\text { 10-15 g/day for first month } \\
20-30 \mathrm{~g} / \text { day afterward }\end{array}$ & $\begin{array}{l}20 \mathrm{~g} / \text { day for first two weeks } \\
20+5 \mathrm{~g} / \text { day until } 10 \mathrm{lbs} \text { from } \\
\text { goal weight } \\
+10 \mathrm{~g} / \text { day until goal weight } \\
\text { reached }\end{array}$ \\
\hline $\begin{array}{l}\text { How are foods } \\
\text { measured? }\end{array}$ & $\begin{array}{l}\text { Weighted on digital gram } \\
\text { scale }\end{array}$ & Weighted on digital gram scale & $\begin{array}{l}\text { Using household } \\
\text { measurements, } \\
\text { exchange lists or } \\
\text { estimated }\end{array}$ & Uses exchange lists & Estimated & Estimated \\
\hline Calories controlled & Yes & Yes & Yes & Yes & No & No \\
\hline $\begin{array}{l}\text { Presence of urine } \\
\text { ketones }\end{array}$ & Yes & Yes & No & $\begin{array}{l}\text { Yes }{ }^{\mathrm{a}} \text { but may need the higher } \\
\text { amount of MCT and or ratio } \\
\text { adjusted to decrease carb/protein }\end{array}$ & Yes if protein intake controlled & Yes if protein intake controlled \\
\hline
\end{tabular}

${ }^{a}$ Diets adjusted to 1,800 kcal diet for comparison purposes only.

$L C T$, long-chain triglycerides; $M C T$, medium-chain triglyceride. 
8. Because of the strictness and limitations of the KD, socializing with friends and family around a meal can be difficult.

9. Six weeks of compliance with the KD was tolerable by most patients and caregivers.

10. Little is known about the efficacy of the $\mathrm{KD}$ in treating cancers in humans. Thus, adherence to the strict diet and the documentations of ketosis are imperative to evaluate fairly whether the KD is an effective treatment.

11. Strong alliance between the research staff, the patients, family caregivers, dietitians, and oncology physicians is necessary for the success in completing this research.

12. In our most recent protocol, the patients are concurrently receiving radiation and chemotherapy. Possible therapy side effects of nausea and other gastric distress symptoms may be exacerbated by the $\mathrm{KD}$. Of the eight patients treated, only 1 patient had nausea and decreased appetite, which were attributed to chemotherapy and radiation therapy by her treating physicians.

\section{CONCLUSION}

There are both in vitro and in vivo animal studies to suggest that $\mathrm{KD}$ has the potential to augment the treatments currently

\section{REFERENCES}

1. Siegel R, Naishadham D, Jemal A. Cancer statistics, 2013. CA Cancer J Clin (2013) 63(1):11-30. doi:10.3322/caac.21166

2. Ostrom QT, Gittleman H, Fulop J, Liu M, Blanda R, Kromer C, et al. CBTRUS statistical report: primary brain and central nervous system tumors diagnosed in the United States in 2008-2012. Neuro Oncol (2015) 17(Suppl 4):iv1-62. doi:10.1093/neuonc/nov189

3. Buckner JC, Brown PD, O’Neill BP, Meyer FB, Wetmore CJ, Uhm JH. Central nervous system tumors. Mayo Clin Proc (2007) 82(10):1271-86. doi:10.4065/82.10.1271

4. Clarke J, Butowski N, Chang S. Recent advances in therapy for glioblastoma. Arch Neurol (2010) 67(3):279-83. doi:10.1001/archneurol.2010.5

5. Stupp R, Mason WP, van den Bent MJ, Weller M, Fisher B, Taphoorn MJB, et al. Radiotherapy plus concomitant and adjuvant temozolomide for glioblastoma. New Engl J Med (2005) 352(10):987-96. doi:10.1056/NEJMoa043330

6. Jeswani S, Nuno M, Folkerts V, Mukherjee D, Black KL, Patil CG. Comparison of survival between cerebellar and supratentorial gioblastoma patients: surveillance, epidemiology, and end results (SEER) analysis. Neurosurgery (2013) 73(2):240-6. doi:10.1227/01.neu.0000430288.85680.37

7. Kroemer G, Pouyssegur J. Tumor cell metabolism: cancer's Achilles' heel. Cancer Cell (2008) 13:472-82. doi:10.1016/j.ccr.2008.05.005

8. Fredericks M, Ramsey RB. 3-Oxo acid coenzyme A transferase activity in brain and tumors of the nervous system. J Neurochem (1978) 31:1529-31. doi:10.1111/j.1471-4159.1978.tb06581.x

9. Mauer GD, Brucker DP, Bahr O, Harter PN, Hattingen E, Walenta S, et al. Differential utilization of ketone bodies by neurons and glioma cell lines: a rationale for ketogenic diet as experimental glioma therapy. BMC Cancer (2011) 11:315. doi:10.1186/1471-2407-11-315

10. Chang HT, Olson LK, Schwarz KA. Ketolytic and glycolytic enzymatic expression profiles in malignant gliomas: implication for ketogenic diet. Nutr Metab (2013) 10:47. doi:10.1186/1743-7075-10-47

11. Artzi M, Liberman G, Vaisman N, Bokstein F, Vitinshtein F, Aizenstein O, et al. Changes in cerebral metabolism during ketogenic diet in patients with primary brain tumors: 1H-MRS study. J Neurooncol (2017) 132(2):267-75. doi:10.1007/s11060-016-2364-x

12. Link TW, Woodworth GF, Chaichana KL, Grossman SA, Mayer RS, Brem H, et al. Hyperglycemia is independently associated with post-operative function loss in patients with primary eloquent glioblastoma. J Clin Neurosci (2012) 19(7):996-1000. doi:10.1016/j.jocn.2011.09.031 available for patients with aggressive gliomas. The value of $\mathrm{KD}$ to treat humans with these malignancies has yet to be proven in clinical trials. There is currently a lack of standard KD protocols so that comparison of different trials is difficult. Rigorous diet management and objective measures of ketosis are required to fairly evaluate the effectiveness of the $\mathrm{KD}$ as therapy for aggressive gliomas.

\section{AUTHOR CONTRIBUTIONS}

KS wrote the manuscript and edited the tables and figures. MNoel conceptualized the review and helped to prepare the tables and figures. MNikolai helped with writing the manuscript and with the preparation of the tables and figures. HC helped with the preparation of the manuscript. All authors helped, read, edited, and approved the final manuscript.

\section{FUNDING}

Funding was received from American Institute for Cancer Research, \#207193 VFW auxiliary, Eaton Rapids, MI, USA.

13. Mayer A, Vaupel P, Struss H-G, Giese A, Stockinger M, Schmidberger H Strong adverse prognostic impact of hyperglycemic episodes during adjuvant chemoradiotherapy of glioblastoma multiforme. Strahlenther Onkol (2014) 190(10):933-8. doi:10.1007/s00066-014-0696-Z

14. Shimazu T, Hirschey MD, Newman J, He W, Shirakawa K, Le Moan N, et al. Suppression of oxidative stress by $\beta$-hydroxybutyrate, an endogenous histone deacetylase inhibitor. Science (2013) 339(6116):211-4. doi:10.1126/ science. 1227166

15. Woolf EC, Curley KL, Qingwei L, Turner GH, Charlton JA, Preul MC, et al. The ketogenic diet alters the hypoxic response and affects expression of proteins associated with angiogenesis. Invasive potential and vascular permeability in a mouse glioma model. PLoS One (2015) 10(6):e0130357. doi:10.1371/journal. pone. 0130357

16. Greco T, Glenn TC, Hovda DA, Prins ML. Ketogenic diet decreases oxidative stress and improves mitochondrial respiratory complex activity. J Cereb Blood Flow Metab (2016) 36(9):1603-13. doi:10.1177/0271678X15610584

17. Maalouf MA, Rho JM, Mattson MP. The neuroprotective properties of calorie restriction, the ketogenic diet, and ketone bodies. Brain Res Rev (2009) 59(2):293-315. doi:10.1016/j.brainresrev.2008.09.002

18. Seyfried TN, Kiebish MA, Marsh J, Shelton LM, Huysentruyt LC, Mukherjee P. Metabolic management of brain cancer. Biochim Biophys Acta (2011) 1807(6):577-94. doi:10.1016/j.bbabio.2010.08.009

19. Mukherjee P, El-Abbadi M, Kasperzyk J, Ranes M, Seyfried T. Dietary restriction reduces angiogenesis and growth in an orthotopic mouse brain tumour model. Br J Cancer (2002) 86:1615-21. doi:10.1038/sj.bjc.6600298

20. Marsh J, Mukherjee P, Seyfried TN. Drug/diet synergy for managing malignant astrocytoma in mice: 2-deoxy-D-glucose and the restricted ketogenic diet. Nutr Metab (2008) 5(1):33. doi:10.1186/1743-7075-5-33

21. Martuscello RT, Vedam-Mai V, McCarthy DJ, Schmoll ME, Jundi MA, Louviere CD, et al. A supplemented high-fat low-carbohydrate diet for the treatment of glioblastoma. Clin Cancer Res (2016) 22(10):2482-95. doi:10.1158/1078-0432. CCR-15-0916

22. Allen BG, Bhatia SK, Anderson CM, Eichenberger-Gilmore JM, Sibenaller ZA, Mapuskar KA, et al. Ketogenic diets as an adjuvant cancer therapy: history and potential mechanism. Redox Biol (2014) 2:963-70. doi:10.1016/j.redox.2014.08.002

23. Winter SF, Loebel F, Dietrich J. Role of ketogenic metabolic therapy in malignant glioma: a systematic review. Crit Rev Oncol Hematol (2017) 112:41-58. doi:10.1016/j.critrevonc.2017.02.016

24. Schwartz K, Chang HT, Nikolai M, Pernicone J, Rhee S, Olson K, et al. Treatment of glioma patients with ketogenic diets: report of two cases treated 
with an IRB-approved energy-restricted ketogenic diet protocol and review of the literature. Cancer Metab (2015) 3(3):1-10. doi:10.1186/s40170-015-0129-1

25. Lefevre F, Aronson N. Ketogenic diet for the treatment of refractory epilepsy in children: a systematic review of efficacy. Pediatrics (2000) 105(4):e46. doi:10.1542/peds.105.4.e46

26. Klein P, Janousek J, Barber A, Weissberger R. Ketogenic diet treatment in adults with refractory epilepsy. Epilepsy Behav (2010) 19(4):575-9. doi:10.1016/j. yebeh.2010.09.016

27. Patel A, Pyzik PL, Turner Z, Rubenstein JE, Kossoff EH. Long-term outcomes of children treated with the ketogenic diet in the past. Epilepsia (2010) 51(7):1277-82. doi:10.1111/j.1528-1167.2009.02488.x

28. Strowd RE, Grossman SA. The role of glucose modulation and dietary supplementation in patients with central nervous system tumors. Curr Treat Options Oncol (2015) 16(8):36. doi:10.1007/s11864-015-0356-2

29. Abdelwahab M, Fenton K, Preul M, Rho J, Lynch A, Stafford P, et al. The ketogenic diet is an effective adjuvant to radiation therapy for the treatment of malignant glioma. PLoS One (2012) 7:e36197. doi:10.1371/journal.pone.0036197

30. Freeman JM, Kossoff EH, Freeman JB, Kelly MT. The Ketogenic Diet: A Treatment for Children and Others with Epilepsy. New York: Demos (2007).

31. Muzykewicz DA, Lyczkowski DA, Memon N, Conant KD, Pfeifer HH, Thiele EA. Efficacy, safety, and tolerability of the low glycemic index treatment in pediatric epilepsy. Epilepsia (2009) 50(5):1118-26. doi:10.1111/j.1528-1167. 2008.01959.x

32. Sharma S, Sankhyan N, Gulati S, Agarwala A. Use of the modified Atkins diet for treatment of refractory childhood epilepsy: a randomized controlled trial. Epilepsia (2013) 54(3):481-6. doi:10.1111/epi.12069

33. Westman EC, Phinney SD, Vollek J. New Atkins Diet for a New You. New York: Simon and Shuster (2010).

34. Kossoff EH, McGrogan JR, Blumi RM, Pillas DJ, Rubenstein JE, Vining EP. A modified Atkins diet is effective for the treatment of intractable pediatric epilepsy. Epilepsia (2006) 47(2):421-4. doi:10.1111/j.1528-1167.2006.00438.x

35. Freeman JM, Kossoff EH, Hartman AL. The ketogenic diet: one decade later. Pediatrics (2007) 119(3):535-43. doi:10.1542/peds.2006-2447

36. Nebeling LC, Miraldi F, Shurin SB, Lerner E. Effects of a ketogenic diet on tumor metabolism and nutritional status in pediatric oncology patients: two case reports. J Am Coll Nutr (1995) 14(2):202-8.
37. Kalamian M, Zupec-Kania B, Favara BE, Liepa GU. Ketogenic diet as adjunctive therapy for brain tumors. First International Symposium on The Ketogenic Diet for Epilepsy and Other Neurological Disorders. Phoeniz, AZ: Barrows Neurological Institute (2008).

38. Zuccoli G, Marcello N, Pisanello A, Servadei F, Vaccaro S, Mukherjee P, et al. Metabolic management of glioblastoma multiforme using standard therapy together with a restricted ketogenic diet: case report. Nutr Metab (2010) 7(1):33. doi:10.1186/1743-7075-7-33

39. Klein P. Mid-atlantic epilepsy and sleep center, LLC University of Pittsburgh. Ketogenic diet as adjuvant treatment in refractory/end-stage glioblastoma multiforme: a pilot study. Curr Recruit (2013). Available from: https://clinicaltrials.gov/ct2/show/NCT01865162?term=ketogenic

40. Scheck AC. Phase I/II prospective trial for newly diagnosed GBM, With Upfront Gross or Subtotal Resection, Followed by Ketogenic Diet with Radiotherapy and Concurrent Temodar Chemotherapy Followed by adjuvant Temodar Chemotherapy: Recruiting. (2016). Available from: https://clinicaltrials.gov/ ct2/show/NCT02046187?term=ketogenic+diet\&rank=8

41. Rieger J, Baehr O, Hattingen E, Maurer G, Coy J, Weller M, et al. The ERGO trial: A pilot study of a ketogenic diet in patients with recurrent glioblastoma. J Clin Oncol (2010) 28(15_Suppl):e12532. doi:10.1200/jco.2010.28.15_suppl. e12532

42. Schwartz K. Pilot Study of a Metabolic Nutritional Therapy for the Management jof Primary Brain Tumors Recruiting. (2012). Available from: https:/ clinicaltrialsgov/ct2/show/NCT01535911?term=ketogenic+diet\&rank=34

Conflict of Interest Statement: The authors declare that the research was conducted in the absence of any commercial or financial relationships that could be construed as a potential conflict of interest.

Copyright () 2018 Schwartz, Noel, Nikolai and Chang. This is an open-access article distributed under the terms of the Creative Commons Attribution License (CC BY). The use, distribution or reproduction in other forums is permitted, provided the original author(s) and the copyright owner are credited and that the original publication in this journal is cited, in accordance with accepted academic practice. No use, distribution or reproduction is permitted which does not comply with these terms. 